\title{
Oil crops in biofuel applications: South Africa gearing up for a bio-based economy
}

\author{
BB Marvey*
}

\begin{abstract}
Large fluctuations in crude oil prices and the diminishing oil supply have left economies vulnerable to energy shortages thus placing an enormous pressure on nations around the world to seriously consider alternative renewable resources as feedstock in biofuel applications. Apart from energy security reasons, biofuels offer other advantages over their petroleum counterparts in that they contribute to the reduction in greenhouse gas emissions and to sustainable development. Just a few decades after discontinuing its large scale production of bioethanol for use as engine fuel, South Africa (SA) is again on its way to resuscitating its biofuel industry. Herein an overview is presented on South Africa's oilseed and biofuel production, biofuels industrial strategy, industry readiness, challenges in switching to biofuels and the strategies to overcome potential obstacles.
\end{abstract}

Keywords: Food crops, biofuel, South Africa (SA).

Disciplines: Chemistry, Energy Studies, Agricultural Studies.

\section{Introduction}

The diminishing crude oil supply and the concern over the impact of Greenhouse Gas (GHG) emissions on the earth's climate (i.e. global warming) have been a driving force on nations around the world to seriously consider investing in clean and sustainable solutions for fuels, polymers and chemicals. Some analysts are in fact predicting that prices for petrol and other fuel should reach disastrous levels soon after 2010 with oil production levels reaching their maximum (Jones, 2003). If this was to be the case, then alternative fuels must phase in much faster to complement fossil fuels whose supply is fast dwindling. For this reason biofuels are receiving substantial attention as renewable alternatives to petroleum-based fuels. Although not as yet competitive as fossil fuels in terms of profitability (Auer, 2005), biofuels offer numerous advantages over their petroleum counterparts in that they contribute to the reduction in greenhouse gas emissions, sustainable development and to energy security (Katemgo, 2007).

* Department of Chemistry, University of Limpopo, MEDUNSA, South Africa. Tel: +27-12 5214367. Fax: +27-12 521 5809, E- mail: bbmche@gmail.ac.za 
In Africa today, as in most parts of the world, the biofuel industry is receiving serious attention in view of the vast land available and the favourable climate for growing many of the energy crops. For South Africa biofuel production is not a new concept altogether. In the 1920s to 1960s South Africa used bioethanol from sugar cane as transportation fuel until such time when international crude oil prices fell to their lows (BIS, 2007). With recent increases in crude oil price, South Africa has once again shown interest in biofuel production with a number of potential investors already expressing interest for investing in this market (BIS, 2007). In terms of the biofuels industrial strategy of the Republic of South Africa, some seed crops have been identified in the initial phase of the development of the biofuel industry, namely, sunflower, canola, and soya beans. Besides these three, other oilseed crops such as Jatropha curcas and Moringa oleifera have also been earmarked for biodiesel production (Le Roux, 2007). In this paper, South Africa's oilseed and biofuel production, biofuels industrial strategy, industry readiness, challenges anticipated in the biobased economy and the strategies to handle those challenges are discussed.

\section{South African oilseed production}

South Africa has available cultivated land to grow crops for local consumption and for export purposes. However, there is concern that enough is not produced to offset highly priced grain and oilseed imports (The Times 26/04/08). According to the information provided by SA's department of minerals and energy (dme) about $14 \%$ of the national arable land is under-utilised. Grains and seeds that are currently grown for commercial purposes include maize, sunflower, soya beans, sorghum, groundnuts, dry beans, wheat, barley, canola and sweet lupines. Important oilseed crops in the list are sunflower, soybean, groundnuts and canola (rapeseed) (FTDB, 2008) and those targeted for biodiesel production in South Africa, are sunflower, soya bean and canola (BIS, 2007). Figure 1 shows oilseed production figures for 2005/06 and 2006/07. The production figures indicate a general decline in oilseed yield from 2005/06 to 2006/07 and a corresponding decrease of the area planted, thus confirming the concern over oilseed underproduction and land under-utilisation. ${ }^{1}$ The 2008 production forecasts, however, seem to be geared up for improvement. For sunflower seed the production forecast is 785880 tons, which is $162 \%$ more than the 300000 tons obtained the previous season, according to the RSA Food Security Bulletin (04/2008). For soya beans the production forecast is 302250 tons, a $47 \%$ improvement over the previous season.

The production forecast for groundnut is 82185 tons, which represents $41.7 \%$ improvement over previous season and for canola the expected area planted shows a decrease by $0.6 \%$. Sunflower crop (Helianthus annuus L.,) is the most important oilseed crop in Southern Africa (FTDB, 2008) and native to South Africa and North America (Commodity online.com). In South Africa, sunflower seed is used primarily for making oil and animal feed. The total oil content after crushing amounts to $40 \%$ of the total seed and this is used for edible purposes (e.g. in cooking, margarine and salad dressings) and for industrial use (e.g. manufacturing of cosmetics and skin creams, paints, shoe polish, etc.). Sunflower oil cake, a byproduct of the oil extraction process, constitutes $44 \%$ and is mainly used as an important protein ingredient in animal feed and for breakfast cereals. The remaining 16\% is waste (Van Schalkwyk, 2003).

1. Pie graphs are not a very useful way to represent these numbers. I calculated the total oilseed production in 2005/6 to be 957082 tons from 793600 Ha.. This is an average of 1.2 Tons/Ha. For 2006/07 543449 Ha was under cultivation producing $567369 \mathrm{~T}$, an average of 1.04 Tons/Ha. Figure 1 does not show this trend nicely although agree with the message. 
Soya bean (Glycine max) is a legume native to East Asia (cyberlipid.org; wikipedia.org) and an important oil crop providing oil and protein. The oil content amounts to $20 \%$ of the total seed whilst the protein content is about $40 \%$. The rest consists of $35 \%$ carbohydrate and about $5 \%$ ash (wikipedia.org). In South Africa, soya beans are grown primarily for oil and for animal feed and a smaller percentage is used for human consumption. Soya bean oil is commonly used in bath oil and soap making formulations (fromnaturewithlove.com).

Groundnuts, also known as peanuts or earthnuts are used as food for humans and livestock and provide a valuable dietary protein in the absence of meat (Olajide, 2007). In South Africa, groundnuts are used mainly for human consumption with $26 \%$ consumed in their primary form whether shelled or unshelled (Van Schalkwyk, 2003). However, a projection for the 2006/07 season was to have 3000 tons of groundnuts used for oil and oilcake, 23000 tons for peanut butter and 34000 tons for the edible market (FTDB, 2008). Groundnut oil rates the sixth most important vegetable oil in terms metric tons produced (Olajide, 2007) with Africa producing a quarter of the world's total production in 1997 (Spore, 1998). The oil is used for cooking, in salad oils and as an ingredient for mayonnaise and margarine production (Van Schalkwyk, 2003).

Canola crop, a genetically modified species from rapeseed plant, is used in South Africa mainly for providing cooking oil and for animal feed (FTDB, 2008). Unlike other major oil crops such as sunflower, soya bean and groundnuts which are summer crops, canola is a dry land winter crop; a characteristic which makes it suitable as a rotational and complementary crop to the existing oilseed crops. Canola oil has superior properties as a salad and cooking oil and is suitable for margarine and shortening blends (Downey, 1990).

(a)

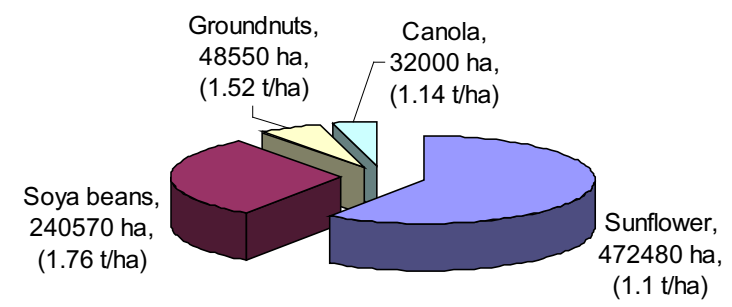

(b)

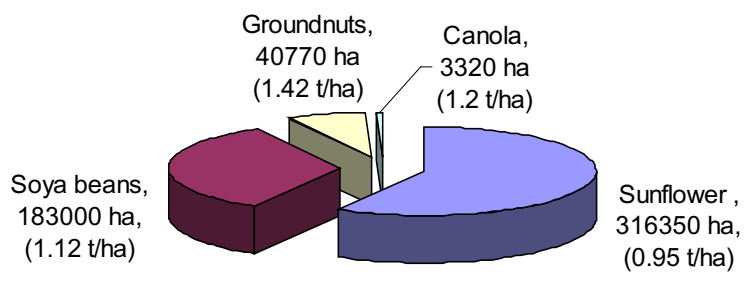

Figure 1. SA's oilseed production for (a) 2005/06 and (b) 2006/07 showing area planted (ha) and yield (t/ha). Source: CEC, 2008. 


\section{Applications in biofuel}

Oilseed crops have attracted much attention as potential renewable sources of raw material for liquid fuel compatible and blendable with current fuels. With the rising focus on renewable energy sources, oilseed crops are good candidates as sources of biodiesel. Amongst seed oils available in SA for biodiesel production are soya bean, sunflower, canola and peanut oils. On the other hand, crops such as maize and sugarcane are attractive sources of bioethanol. Figure 2 illustrates processes from biomass to biodiesel and bioethanol. Biodiesel is produced by transesterification of seed oils with methyl or ethyl alcohol in the presence of a suitable catalyst. The glycerol byproduct constitutes about $10 \mathrm{wt} \%$ of the total product (Meier, 2007). The biodiesel produced could then be used in diesel engines neat or blended with petroleum diesel. Neat biodiesel (B100) can be used in some engines with little or no modification whereas blends of $20 \%$ biodiesel and $80 \%$ petroleum diesel (B20) or less could be used in most diesel engines without any engine modification (Zanzi et al., 2006). The glycerol produced as byproduct offers new other interesting possibilities, for example, as a starting material in the production of propylene glycol, 1,3-propanediol and epichlorohydrin. Recently the Dow Chemical Co. has revealed its intention of producing propylene glycol from glycerol (ref). Other companies such as Huntsman corp., CargillAshland and Archer Daniels Midland have also shown similar interest to that of Dow. In addition, Dow will also produce epichlorohydrin from glycerol, an undertaking that Solvay intends doing also (Meier et al. 2007).

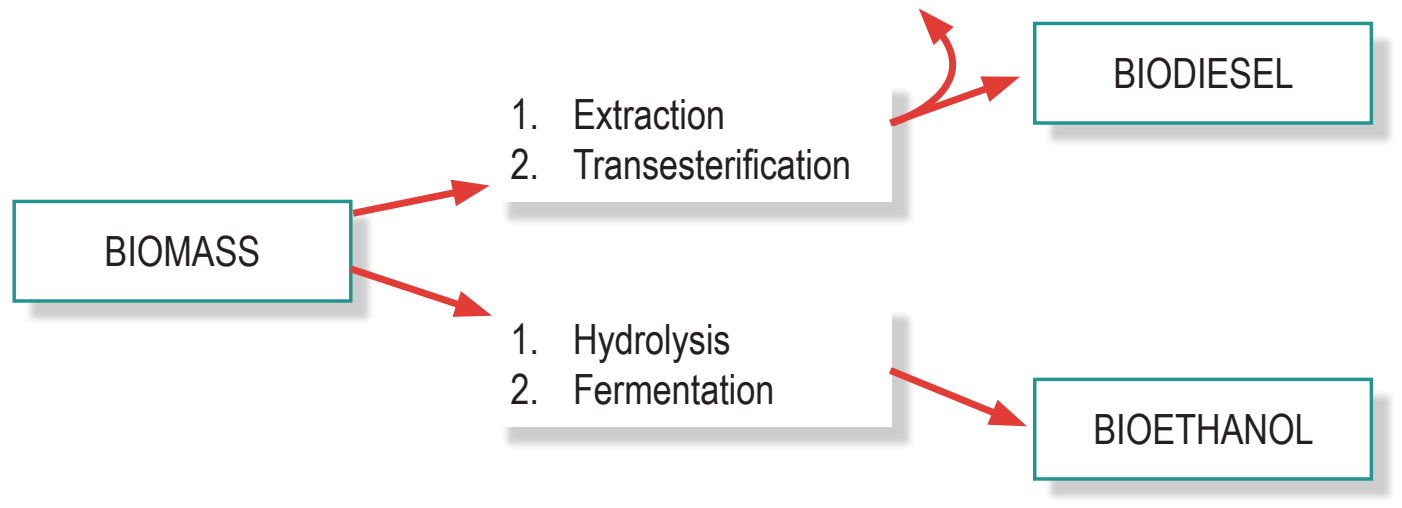

Figure 2. Biofuel production from biomass

As shown in Table 1, differences in fuel properties exist between petroleum diesel, biodiesel and a pure vegetable oil (Hofman, 2003). In this Table the heat of combustion, viscosity, CN, pour point and cloud point for soyabean oil, methyl soyate (biodiesel), B20 diesel blend and No.2 diesel fuel (DF2) are compared. Neat seed oils have a very high viscosity and relatively low cetane numbers $(\mathrm{CN})$. As a result they are not the best choice as diesel substitutes due to their poor ignition quality and engine problems such as nozzle coking and engine deposits. Cetane number is an index used to determine the fuel's ignition time delay (Radich, 2004; GC Bio Fuel) whilst nozzle coking and engine deposits could be linked to the high viscosity of vegetable oils (Bruwer et al., 1980(a) and (b)). Heat of combustion, cloud point and pour point are other fuel properties indicating suitability of fatty oils as diesel fuel (Knothe, 2005). Cloud point is the temperature at which liquid fuel becomes cloudy as it turns into solid or crystal form. Pour point is the lowest temperature at which the fuel can still flow (Knothe, 2005) and fuels with a high heat of combustion will usually produce more power per kilogram of fuel than fuels with lower 
energy (Hofman, 2003).

Table 1. Properties of selected diesel fuels ${ }^{2}$

\begin{tabular}{|l|c|c|c|c|}
\hline & $\begin{array}{c}\text { Pure Soya } \\
\text { bean oil }\end{array}$ & $\begin{array}{c}\text { Methyl } \\
\text { Soyate }\end{array}$ & B20 mix & $\begin{array}{c}\text { No.2 Diesel } \\
\text { Fuel }\end{array}$ \\
\hline Heat of combustion $(\mathrm{kJ} / \mathrm{kg})$ & 39,623 & 39,800 & 42,723 & 45,343 \\
\hline Viscosity $\left(\mathrm{mm}^{2} / \mathrm{s}\right)$ & 32.6 & 4.08 & 3.3 & 2.07 \\
\hline Cetane no. & 37.9 & 46.2 & 50 & 47.0 \\
\hline Pour point $\left({ }^{\circ} \mathrm{C}\right)$ & -12.2 & -1 & -45.6 & -33 \\
\hline Cloud point $\left({ }^{\circ} \mathrm{C}\right)$ & -3.9 & 2 & -14.4 & -15 \\
\hline
\end{tabular}

\section{SA's biofuels strategy and industry readiness}

For biofuel production in SA the following crops have been targeted: sugar cane and sugar beet for bioethanol, and sunflower, canola and soya beans for biodiesel. For food security reasons basic food crops like maize have been excluded in the initial stages of a biofuel drive and additional land for growing biofuel crops will come from the $14 \%$ currently under-utilised arable land which is located mainly in the former homelands. Therefore in addition to addressing pressing energy needs, the biofuel strategy seeks to boost the agricultural sector in farming areas previously marginalised by the apartheid system and to create sustainable income-earning opportunities especially for the rural poor. It is estimated that a $2 \%$ biofuel penetration level will create 25000 jobs which is a reduction of rural unemployment by $0.6 \%$ and a boost to economic growth by $0.05 \%$. The current fuel levy exemptions are $40 \%$ for biodiesel and a proposed $100 \%$ for bioethanol. A further increase to $50 \%$ biodiesel levy exemption has been proposed after which the absolute value of the support will increase with increases in the fuel levy. The decision to exempt bioethanol from levies was because this fuel can be used in other markets where no levies are charged. For example, ethanol gel competes with illuminating paraffin which carries no levies.

Companies that have shown interest to invest in SA's biofuel project include the Australian-owned Rainbow Nation Renewable Fuels (RNRF), Ethanol Africa, Sasol (SA's largest fuel producer), to name a few. RNRF is in the final stages of securing a government license to manufacture soya-based biodiesel at Coega-based plant (Eastern Cape) with an initial investment of R1.5 billion. The plant would be the biggest in Africa producing an estimated 288 million litres of biodiesel per annum which is around 3\% of South Africa's diesel fuel needs and creating about 350 new direct jobs and 725 indirect jobs. According to Geoff Mordt, the managing director of RNRF, negotiations are already under way with interested transport and mining companies and with local agricultural corporations and farmers. Predictions indicate that the plant should be operational by September 2009 and apparently the process of switching to biodiesel will not be a major challenge since the great majority of modern passenger and commercial vehicles are able to run on B5 diesel which is a blend made from 5\% biodiesel and 95\% petroleum diesel. The East London Industrial Development Zone (ELIDZ) has in the mean time identified canola as fuel for its refinery. 
Ethanol Africa announced in 2006 of its plans to build maize-to-ethanol plants in SA at a cost of $\$ 1$ billion. The company planned to build eight biofuels plants near Bothaville south of Johannesburg but then stopped construction to assess funding options and government support. According to Greg Jones of Sterling Waterford Holdings Ltd which owns a stake in Ethanol Africa, the project is on hold until government finalizes its policy on biofuels strategy. Bioethanol is an alcohol-based fuel obtained by fermenting starch or sugar in a wide variety of crops (Figure 2). In USA most cars on the road can run on bioethanol-petrol blends of up to $10 \%$ ethanol, and the use of $10 \%$ ethanol petrol is mandated in some cities where harmful levels of auto emissions are possible.

Meanwhile Sasol is reviewing its plans to put up a soy-based fuels plant due to its dissatisfaction with government support towards the biofuel project. Sasol had earlier indicated its intentions to produce 80 000 tons per annum of biodiesel from 400000 tons of soya beans. The project would require about 300 000 hectares of extra soya beans to be grown each year for it to run at full capacity.

\section{Challenges and strategies}

Although biofuels are an attractive alternative to petrofuel and would reduce the vulnerability of world economies to price increases in crude oil, there still remain few challenges to address to make them competitive as main stream energy sources. Among the challenges are:

- food security;

- the high cost of feedstock; and

- fuel quality.

Since biofuel comes mainly from food crops such as maize, sugar cane and various oil crops, this clearly creates a food versus fuel dilemma. To have biofuel plants running and a sustainable supply of biofuel, a significant fraction of the national annual crop production should be apportioned for fuel production. To overcome this dilemma, Shah and Colantuani (2008) are of the view that a "new agriculture" be developed that will not compete with food crops for land use, for example, the use of algae in biofuel production.

Other alternatives to food crops would include the use of non-edible plants such as switchgrass, wood and agricultural residues for bioethanol. As a strategy to overcome this challenge, South Africa has agreed to exclude crops such as maize, which provide staple food for most South Africans, from the targeted crops for biofuels. To further minimise food security risks, a $2 \%$ penetration level of biofuels in the national liquid fuel supply has been proposed, which amounts to 400 million litres per annum. This requires about $1.4 \%$ of arable land. The land targeted for the biofuel project is the currently underutilized land in the former homelands. Feedstock for biofuel would, therefore, come from surplus crops and from underutilized land. Equally important for the viability of biofuels are the cost of feedstock, its conversion to biofuel and the cost on the consumer.

At the moment the cost of feedstock for biodiesel manufacturing is very high (Shah and Colantuani, 
2008). However, research has shown that when a B20 blend is used with some form of tax exemption on the biodiesel portion, the price per litre of biodiesel ranges close to or is slightly less than the retail price of fully taxed petro-diesel (Schmidt, 2004).

The quality of biodiesel is another serious challenge to overcome. Biodiesel from different sources tends to have different fatty acid profiles, a quality which influences its cold flow properties and oxidative stability. Tallow and palm oil based biodiesel, for example, show poor low temperature flow properties as compared to soybean and canola based biodiesel which have a relatively higher composition of monoand polyunsaturated fatty acids. On the other hand, biodiesel consisting of highly unsaturated fatty acid esters is more susceptible to oxidation than biodiesel with a high composition of saturated fatty acid esters (Shah and Colantuani, 2008). In general, neat biodiesel (B100) has been found to perform very poorly in cold temperatures compared to petro-diesel. The poor cold flow properties are indicated by their relatively high cloud points and pour points (Knothe, 2005). However, a B20 blend shows no operational problems down to temperatures as low as $-40{ }^{\circ} \mathrm{C}$.

\section{Summary and concluding remarks}

With the petroleum age nearing its end, biofuels are gradually taking centre stage as renewable alternatives to petro-fuels. A biobased economy is expected to reduce the vulnerability of economies to price increases in crude oil and fuels. To ensure energy security and to pledge a support for reduced greenhouse gas emissions and the promotion of sustainable development, the South African government faces the challenge of showing a strong commitment for the biofuel industry through their policy regulations and incentives. A policy framework which is reliable and objective-oriented is essential for the integration of biofuels to be successful. Through concerted efforts and by addressing the concerns around biofuel quality, biofuels from oil crops and non-edible plants could significantly contribute towards reducing global dependence on petro fuels. Indeed biofuels are part of the solution and not the only solution to energy demands. The approach to addressing the energy demands should incorporate all renewable energy resources including solar and hydropower as they each have a role to play.

\section{References and notes}

Auer, J. (2005). Bioenergies after the petroleum age, Deutsche Bank Research, http://www.dbresearch.com (accessed June 2008).

Biofuels Industrial Strategy (BIS) of the Republic of South Africa (2007). Department of Minerals and Energy, http:// www.info.gov.za/view/DownloadFileAction?id=77830 (accessed October 2008).

Biodiesel. Cold flow properties of biodiesel blends. http://wwwbiodiesel.org/resources/ reportsdatabase/viewall.asp, (accessed December 2008).

Bruwer, J.J.; Boschoff, B.; Van, D.; Hugo, F.J.C.; Fuls J.; Hawkins, C.; van der Walt, A.N.; Engelbrecht, A.; du Plessis, L.M. 1980 (a). In The Utilization of Sunflower Seed Oil as a Renewable Fuel for Diesel Engines, American Society for Agricultural Engineers National Energy Symposium, Kansas City, Missouri. 
Bruwer, J.J.; Boschoff, B.; Van, D., Hugo, F.J.C.; Fuls, J.; Hawkins, C.; van der Walt, A.N.; Engelbrecht, A.; du Plessis, L.M. 1980 (b). In Sunflower Seed Oil as Extender for Diesel Fuel in Agricultural Tractors, South African Institute for Agricultural Engineers Symposium.

Clark, S.J.; Wagner L.; Schrock, M.D.; Piennaar, P.G. (1984). Methyl and ethyl soybean esters as renewable fuels for diesel engines. Journal of American Oil Chemists Society, Vol. 61, 1632-1638.

Commodity online. Sunflower.-www.commodityonline.com/commodities/oil.oilseeds/sunfloweroil.php (accessed December 2008).

Crop Estimates Committee (CEC, 28 May 2008). Food security statistics: (a) Final area and crop figures of winter cereals: 2007 production season; (b) Area and fourth production forecast of summer crops: 2007/08 season. www.nda.agric.za (accessed July 2008).

Downey, R.K. (1990). Canola - A quality brassica oilseed, In : J. Janick and J.E. Simon (eds), Advances in new crops. Timber Press, Portland, OR.

Free State Freight Transport Data Bank (FTDB) (2008). Grain and seed production, http://www.freetrans.gov.za/FTD/fs/industries/grain_seeds/index.html (accessed October 2008).

GC Bio Fuel. Alternative Fuel Manufacturers and Equipment Suppliers - Quality, testing and warranties, http://gcbiofuels.com/index.php? ref=quality, (accessed December 2008).

Hofman, V. (2003) Biodiesel Fuel, NDSU Extension Service, http://www.ag.ndsu. nodak.edu (accessed October 2008).

Jones, G. (2003) World oil and gas “running out". http://edition.CNN.com/2003 (accessed October 2008).

Katembo, BI. (2007) Africa, seeds, and biofuel, Journal of Multidisciplinary Research, Vol. 1, 1-6.

Knothe, G. 2005. Dependence of biodiesel fuel properties on the structure of fatty alkyl esters, Fuel Processing Technology, Vol. 86, 1059-1070.

Le Roux, H. (2007). Growing biodiesel, Engineering News, http://www.engineeringnews.co.za/article.php?a_id=110466 (accessed October 2008).

Meier, A.R., Metzger, J., Schubert, U. (2007) Plant oil renewable resources as green alternatives in polymer science, Chemical Society Reviews, Vol. 36, pp 1788-1802.

Njobeni, S. (2006) Algae biodiesel production in South Africa, Oilgae, http://www.oilgae.Com/blog/2006/07/algae.biodiesel.productions-in-south.html (accessed October 2008).

Olajide, J.O., Igbeka J.C., Afolabi, T.J., Emiola, O.A. (2007). Prediction of oil yield from ground kernels in an hydraulic press using artificial neural network (ANN). Journal of Food Engineering, Vol. 81, 643-646.

Radich, A. (2004) Biodiesel, performance, costs, and use, Energy Information Administration, http://www.eia.doe.gov/oiaf/analysispaper/biodiesel/. 
RSA food security bulletin (April 2008). Monthly food security bulletin.

http://www.nda.agric.za, Issued 12 May 2008 (accessed December 2008).

Schmidt, L. (2004). Biodiesel vehicle fuel:GHG reductions, air emissions, supply and economic overview - Discussion paper C3-015. http://www.biofuelcanada-ca/c3\%20Biodiesel\%20Discussion\%20paper.pdf

(accessed December 2008).

Shah, R. Colantuani, V. 2008. Challenges facing the biodiesel industry: focus on biodiesel testing standards, Biofuel Industry News, 8-9.

SPORE (No. 73, February 1998). Vegetable oils: A slippery slope to success.

http://sporearchive.cta.int/spore73/spore73a.pdf (accessed December 2008).

The Times (26 April 2008). So many questions with Lourie Bosman.

www.thetimes.co.za/PrintEdition/Insight/Article.aspx?id=757178.

Van Schalkwyk, H.P. (2003). Demand relations of oilseed products in South Africa. MCom. Dissertation. University of the Free State, South Africa.

Virginia Cooperative Extention (VCE). Biodiesel fuel.

http://www.ext.vt.edu/pubs/ageng/442-880/442-880.html\#L2, (accessed December 2008).

Zanzi, R., Aquilar, P.J.V., Diaz, I.L., Moya, I.H. (2006) Biodiesel fuel production, Cubarsolar 2006, Villa Clara-Cienfuengas, Cuba, pp 17-21 http://hem.fyristorg.com/ zanzi/ paper/ biodiesel-Zanzi-cubasolar.pdf (accessed October 2008). 